Wilson Observatory ; Prof. C. C. Lauritsen, professor of physics in the California Institute of Technology ; Dr. A. L. Loomis, director of the Loomis Laboratories, Tuxedo Park, N.Y. (physics); Prof. J. R. Oppenheimer, professor of physics in the University of California; Prof. J. T. Patterson, director of zoological research in the University of Texas; Prof. Karl Sax, professor of botany in Harvard Univerisity ; Dr. G. G. Simpson, associate curator of vetebrate palæontology in the American Museum of Natural History ; Dr. Joseph Slepian, Westinghouse Electric and Manufacturing Company (electrical engineering); Dr. L. F. Small, National Institute of Health (organic chemistry); Dr. W. M. Stanley, associatie member in biophysics of the Rockefeller Institute for Medical Research; Prof. T. Y. Thomas, professor of mathematics in the University of California at Ios Angeles; Prof. G. B. Wislocki, Parkman professor of anatomy in Harvard University.

\section{University College, Nottingham: Air-Raid Damage}

NotTINGHam University College buildings in Shakespeare Street have been damaged by a high explosive bomb of heavy calibre. The Departments of Mining and Textiles occupy the Shakespeare Street buildings. The Faculties of Arts and Pure Science and the Departments of Engineering are housed in University Park buildings. The main damage was confined to the west wing of the building, the principal lecture theatres and laboratories, though seriously damaged, escaping destruction. The Mining and Fuels Department was almost completely destroyed, including practically the whole of its valuable apparatus.

In the Textiles Department, which was housed in that section of the building formerly occupied by the Natural History Museum until it was transferred to Wollaton Hall, some of the hosiery machinery was salvaged, but much damage was done to the general structure of that part of the building. Blast broke windows, removed doors and blew down plaster, etc., in practically all parts of the building.

\section{German Aircraft Design}

Technical details now available of the new German fighter, Messerschmitt $109 F$, indicate the general trend of enemy aircraft design towards high altitude operation. The machine, a modification of earlier Messerschmitt fighters, is clearly designed not only to reach great heights, but also to retain climb and general manœuvrability at those altitudes, without which the operation of air fighting is at a tactical disadvantage. It is claimed that this design has a service ceiling of $38,000 \mathrm{ft}$., but the attainment of this height alone has little advantage, it being necessary to retain a speed of manœuvre better than the opposing aircraft, for fighting purposes.

The wing area has been increased, an alteration necessary for this effect, but disadvantageous in many other respects. The amount of armament has been decreased to one cannon and two machine guns. Weight reduction is also an advantage for high altitude work, but a lessening of fire power has obvious drawbacks in a fighter. All guns are now enclosed in the body, the outboard ones on the wings being discarded. The concentration of weight nearer the centre of the machine would improve the quickness of the response to lateral control. Possibly it also reduces the weight and complication of the arrangement for heating the guns, as they would be nearer to the engine, the most convenient source of heat available. It is essential in high altitude flying to prevent freezing up of guns, while they are not in action, by some externally applied heat.

\section{Engineering Economy and Esthetics}

THE Council of the Institution of Civil Engineers has recently given consideration to the need to fost $\mathrm{r}$ among engineers the closer study of : $(a)$ the economics of engineering projects ; $(b)$ the organization and management of engineering work; and $(c)$ the relations of rsthetic considerations to engineering design and construction. It is believed that in the period of reconstruction and development which will follow the War these subjects will become of increasing importance, and in the national interest should form a part of the equipment with which engineers should be furnished in order that they may adequately play their part in the task before them. The Council accordingly intends to examine all possible means by which the Institution can influence the better understanding of engineering economics and rsthetics, not only by students resident at the universities, but also by those otherwise engaged in their engineering training, so that eventually a study of these subjects may form an integral part in the recognized education of all engineers.

As a beginning, the Council of the Institution approached the University of Cambridge with an offer to finance for a period of five years a lectureship on the subjects envisaged in the hope that they would in due course form part of the engineering curriculum of the Mechanical Sciences Tripos. The proposal was cordially welcomed, and has now been accepted in principle by the Council of the Senate of the University; but its full adoption will necessitate some reconsideration of the scheme of instruction in the Engineering School and possibly of the Mechanical Sciences Tripos, which it would be impracticable to undertake in war-time. Nevertheless, during the next academical year, a number of eminent engineers and others will be invited to visit the University to give either single lectures or short courses on subjects coming within the terms of the proposal.

\section{Foreign Periodicals in War-time}

THE Association of Special Libraries and Information Bureaux is undertaking a survey in Great Britain of the present position in regard particularly to enemy and enemy-controlled publications, especially the current issues of periodicals. Previous explanatory surveys have confirmed the impression that since the early part of 1940 only very limited supplies of such publications have been arriving in Great Britain ; that they consist mainly of imperfect sets of a relatively few periodicals restricted very largely to departmental libraries that are not accessible to the general public; and that there is 